\title{
Urban Green Development Planning Opportunities and Challenges in Sub-Saharan Africa: Lessons from Bamenda City, Cameroon
}

\author{
Jude Ndzifon Kimengsi (Corresponding author) \\ Department of Geography and Planning, University of Bamenda \\ PO Box 39, Bambili, Cameroon \\ E-mail: jude.kimengsi@catuc.org \\ Zephania Nji Fogwe \\ Department of Geography and Planning, University of Bamenda \\ PO Box 39, Bambili, Cameroon \\ E-mail:nfogwez@yahoo.co.uk
}

Received: June 4, 2017 Accepted: June 22, 2017 Published: June 24, 2017

doi:10.5296/ijgs.v1i1.11440 URL: http://doi.org/10.5296/ijgs.v1i1.11440

\begin{abstract}
World urban areas are increasingly dabbling with the triple challenge of pollution, congestion and environmental degradation. The quest for sanity and healthy urban living led to the introduction of urban green space initiatives. Green space has become primordial in urban areas as it enhances public health, recreation, amenities and property values through its location, accessibility, proximity and serviceability. In a bid to develop an urban green space in Bamenda, the City Council identified the Bamenda escarpment in 2011 for protection. This was followed by a Green City Initiative now captioned the Green City Project. The Bamenda City Council partnering with the UN-Habitat and the Dordrecht/Gorinchem City Councils of the Netherlands seeks to implement an urban greening project with major focus to map out potential areas for creating parks in Bamenda. This project which is a novelty in the rapidly changing urban landscape of Cameroon seeks to contribute to building a green economy that enhances nature, environmental protection and at the same time offers economic and social benefits to its citizens. In this study, we examine the opportunities and challenges of urban greening in Bamenda. Some 50 inhabitants around the escarpment were purposively sampled
\end{abstract}


while council authorities and other stakeholders were interviewed in the Bamenda I municipality in order to assess the opportunities, challenges and prospects for the project. This was complemented by secondary data obtained from the Bamenda City Council. The conclusion drawn is that the initiative will provide opportunities for employment, generate revenue for the City Council and prevent uncontrolled city sprawl against the backdrop of the relatively unstable nature of the foothills (due to mass wasting processes) and land use competition, largely driven by population growth and the daunting task of relocating prior users. We therefore argue in favour of the effective application of urban development policies to restrict encroachment around the area and to engage in slope stabilization where necessary.

Keywords: Urban green space, Bamenda, Urban expansion, Parks

\section{Introduction}

Estimates of the UN-Habitat (2009) held that half of humanity lives in cities, and by 2030, some 60 per cent of the world's people will be urban dwellers as the developing world cities gain an average of 5 million residents every month. Faced with this upsurge, there is a need for harmony among the spatial, social and environmental aspects of the urban centres and their inhabitants. Rapid and uncontrolled urbanization is archetypical of urban centres of the developing world. Such leads to significant alteration of its ecosystems and the loss of urban greenery and habitat (Gairola \& Noresah, 2010) as well as habitat loss in the urban landscape (Mckinney, 2002). This has triggered a myriad of environmental challenges ranging from a reduction in green spaces to ecosystem deterioration (Lee et al., 2005). Urban green spaces are considered as ecosystem resources which are directly (e.g. active or passive recreation) or indirectly (e.g. positive influence on the urban environment) available for users (Tuzin et al, 2002). Such ecosystems have been shaped by the theory of island biogeography and landscape ecology which have both demonstrated that patches of ecosystems embedded in a matrix of different land use (such as green space within a city) are important for supporting specie populations and biodiversity (Forman, 1996; Bender et al., 1998).

Balram and Dragićević (2005) considered urban green spaces as areas covered with vegetation, natural or maintained, public or private, as opposed to areas that are paved or have buildings on them. Community parks, forested lands, and woodlots are examples of green spaces that occur in the urban milieu. Peschardt et al. (2012) defined these spaces as bounded with at least some vegetation, whereas Grahn and Stigsdotter defined urban open green spaces as all types of green outdoor environments in the town or city (2003:6). The setting within urban confines and the existence of vegetation constitutes unifying characteristics of green spaces. Green spaces have equally been defined to include spaces in a natural, undeveloped or developed (e.g. urban squares and sports fields) state that are easily accessible (Cilliers et al., 2015a). Green spaces have contiguous vegetated areas and spaces including artificially created city parks, stands with natural vegetation and land areas such as botanical gardens, as well as isolated street trees, street medians and private gardens. This implies that green spaces are predominantly natural areas, with a sense of quality and the presence of maintained facilities (Shackleton \& Blair, 2013). In the context of city planning, it relates to natural (vegetated), accessible public spaces with maintained facilities that add a specific quality to communities. These qualities include social, ecological, economic, psychological, health and amenity functions (Sutton, 2006; 


\section{Macrothink}

Lange et al., 2007; Cilliers \& Cilliers, 2016) which can be translated into ecosystem services. Increasingly being termed as "green infrastructure", their virtues within cities portray enormous potentials to harbour valued biodiversity including some rare and endangered species in these habitats (Girling \& Kellett, 2005). The development of urban green space is expected to usher in a number of benefits ranging from air and water purification, pollution mitigation, carbon sequestration, microclimate regulation, habitat for urban wildlife, recreational, spiritual and therapeutic value as well as social integration (Milton, 2002; Hague $\&$ Siegel, 2002). They represent key ecological service providers to urbanites as they perform a variety of functions and equally serve as an important pillar for sustainable development (Yli-Pelkonen \& Niemelia, 2005; Sandstrom et al., 2006). Urban green spaces can provide a comprehensive tool for long term protection of environmental sustainability through improving the quality of life and air quality, increasing property value due to their amenity and aesthetic characteristics, and reducing the energy costs of cooling buildings. Such spaces have the potentials to support ecosystem services including recreation and relaxation facilities to urban dwellers and tourists. Such is part of the overwhelming evidence of the stakes and value of urban green spaces in cities towards planning and constructing sustainable or eco-cities of the $21^{\text {st }}$ Century (Atiqul Haq, 2011). In line with the three core pillars of sustainable development, green spaces have a tripartite contribution which is viewed from an economic, social and environmental perspective (Figure 1). Heritage tourism also employs 270,000 people in the UK excluding green spaces, and 466,000 including green space (Ch'ng, 2011).

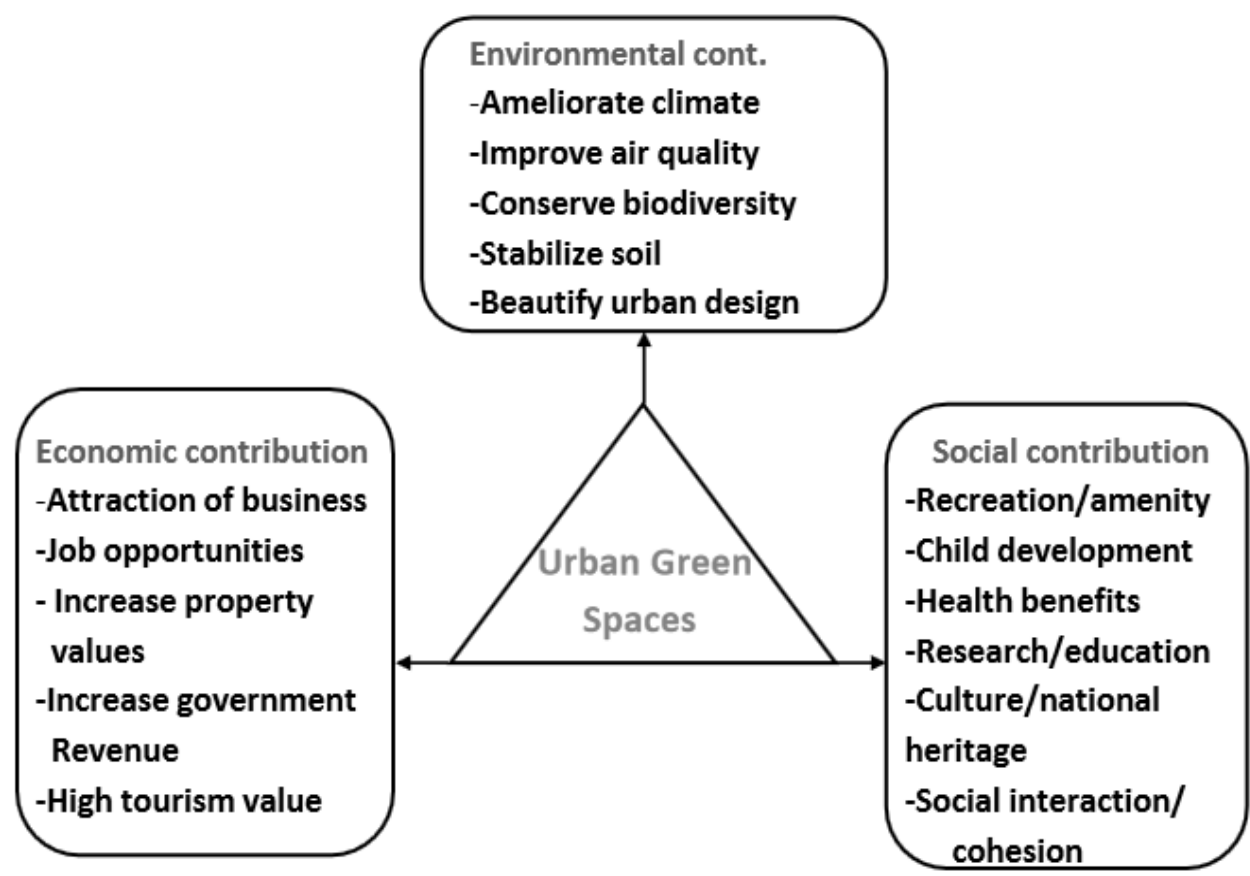

Figure 1. The Tripartite contributions of urban green space

Attaining sustainable urban environments is fast becoming a key obsession of city governments that constantly dabble between containing high density, diversity, mixed land 
uses and sustainable urban forms of green designs that can build ecological cities (Jabareen, 2006). Planning open space in sustainable cities is a worrisome challenge as these spaces compete with additional and alternative urban facility developments for functional service provision. Notwithstanding, open space has remained a crucial amenity (Smith et al., 2002) in fostering urban environment through conviviality and social harmony. It is this quest to preserve the environmental quality of fast developing cities that green spaces are created and managed as an environmental justice mechanism. Urban planning theories and models concur unanimously that by improving such city liveability, it is possible to breach the uneven distribution of green space environmental injustice. This epitomises dual societies characterized by marked differences in income class; with the low-income having less access to green space, parks, or recreational programs as opposed to the high income cohorts (Abercrombie et al., 2008; Dahmann et al., 2010; Jennings et al., 2012). Such environmental injustice in the distribution of urban green space shows that racial/ethnic minorities and low-income people are most likely to have less access to green space, parks, or recreational programs than the affluent (Jennings et al., 2012). Cites have increasingly sought alternative ways to secure specific urban space production through 'urban ecological security' (Hodson \& Marvin, 2009). Dependence has been through the proper management of urban resilience to environmental stressors - landslides, flooding and local heating as well as amenity for a 'healthy' (and profitable) living space (Greater London Assembly, 2011).

The Cameroonian urban landscape portrays remarkable efforts to secure and develop green spaces in some parts of Yaounde (Bois St Anastasie at Warda), Douala (Bonapriso and Bonanjo) and Limbe (Down Beach). Other towns like Bamenda with similar rapid growth are yet to witness such projects that can step up the environmental health of the city. Though the Bamenda City Council has earmarked over 5 hectares of urban land along the slopes of the Bamenda escarpment, the area has been subject to encroachment by agriculturalists whose activities produce repeated slope failure episodes. To restore the ecological health of the area, the city council plans to use and carry out city greening that could at the same time limit private encroachment on it. The fallouts are several and range from preventing material and financial resources spent by the City Council to mitigate its associated hazards, and well managed urban leisure havens, nature conservation, learning and research unit areas, notwithstanding income generation for the Council. This administrative vision needs to be well anchored on a scientific evaluation of the opportunities and challenges in order to prevent the emergence of brown elephant (failed projects) that are common place in various aspects of urban facility conception, planning and maintenance in Sub-Saharan African city areas.

Although the concept of "Green City," has no uniform definition, several central themes help shape and define it. These include energy efficiency, reducing over-reliance on non-renewable energy sources, low-carbon transportation systems, green and resilient infrastructure, waste reduction and management, increased green areas, water cycle management, and integrated planning (Asian Development Bank, 2015). The greening of urban centres in Africa represents a key cornerstone in Africa's green growth and an opportunity to leapfrog the green development process. Urban centres bring together social innovation, skills, infrastructure and energy, food and water security, making them a natural 
focal point for fueling green development and inclusive urbanization. This equally favours structural transformation in African countries which delivers green, inclusive growth and quality employment (UNECA, 2016). In some urban centres in Africa, urban greening projects have been implemented to improve the quality of life and help marginalised citizens of informal settlements in their efforts to adapt to climate variability. This move contributes to the promotion of the sustainable livelihood objectives in such settlements as was the case in South African cities (Sachikonye et al., 2016). Green spaces have registered some success within the African landscape. For instance, in Johannesburg and Durban (South Africa), green space projects were initiated to achieve a number of objectives (Mensah, 2014; Cilliers \& Goosen, 2016). Some of these objectives include the creation of public park identities, the creation of high quality sustainable public spaces, and the need to create urban growth catalysts, among others. These initiatives were found to be successful in delivering their set objectives (Galvin \& Payne, 2010; Cilliers \& Goosen, 2016). In the context of Bamenda, emphasis in this study is on the promotion of green areas. This initiative adheres to the principles of intelligent urbanism. It specifically falls in line with principle one (maintaining a balance with nature) which stresses on the promotion of the assessment of fragile ecosystems and their conservation, and principle four which emphasizes conviviality within the urban space (Fogwe, 2016; Williams, 2003; Benninger, 2001).

\section{The Problem}

Urban environments in the world are increasingly facing the triple effects of pollution, congestion and environmental degradation (Blanco et al., 2009). The corresponding quest for sanity and healthy urban living led to the introduction of urban green space initiatives. Urban green space provides a wide range of ecosystem services that could help combat many urban ills and improve life for city dwellers - especially their health. Green space is diverse, varying in size, vegetation cover, species richness, environmental quality, and proximity to public transport facilities and services (Dahmann et al., 2010; Fuller \& Gaston, 2009). In Cameroon, population increase exerts heavy pressure on basic social services, physical infrastructure and on the environment especially within cities. As a panacea, the government has set up structures specialized in the development of housing, roads and other networks with some important achievements yet dampened by the economic crisis of the 1980s (Cameroon Vision 2035). This has killed the operationalisation and implementation of Urban Development Plans thereby paving the way for anarchical urban morphologies. Cities thus become problem areas interweaving congestion of linear facility networks (water, electricity, and roads), poor sanitation and degradation of the environment, the emergence of squatter settlements, multidimensional criminality, social vices and deviances, disintegrating socio-economic and political bonds, among others. The challenge of urban and regional development is to set up a national integrated economic space capable of controlling urban development and ensuring harmony among the diverse environmental spheres which may be affected by land use changes in urban centres (Cameroon Vision 2035). Previous studies on open space have emphasized their functions and spatial distribution with emphasis on the role played by small areas of green open space as against larger scale parkways, rivers, and stream valleys which connect green networks (Walmsley, 1995). In the Bamenda urban environment, research focus centred on land use dynamics and wetland degradation (Kometa \& Ndi, 2012; Balgah 
\& Kimengsi, 2016; Fogwe, 2016; Fogwe et al., 2016). Issues related to urban green space have so far not received research attention even in the face of escalating population growth and urban development. This is particularly necessary at a time when the Bamenda City Council has embarked on moves towards conserving, restoring and revitalising urban green space against the backdrop of the effects of pressures on this fragile ecosystem. The purpose of this study is to provide scientific thoughts on the urban development planning opportunities of the urban greening project. To develop an urban green space in Bamenda, the Bamenda City Council (BCC) in 2011 identified the slopes of the Bamenda escarpment for protection. This permitted the creation of the Green City Initiative. Together with the UN-Habitat and Dordrecht/Gorinchem City Councils of The Netherlands, the urban greening project shall map out potential areas and create parks in the Bamenda metropolis. Therefore the urban development planning opportunities of the urban greening project needs to be evaluated.

\section{Conceptual Framework}

Urban green projects fall in line with efforts geared towards the attainment of Sustainable Development Goal 11- "Make cities and human settlements inclusive, safe, resilient and sustainable”. A useful framework for the study is the analytical framework for urban green growth (Figure 2) which is applied in the assessment of policies for urban green growth in fast-growing cities (Hammer et al., 2011a). The framework addresses the needs and challenges in these cities and suggests that to develop a policy model for urban green growth, a number of elements require special attention, they include, policy strategies for green growth in fast-growing cities, drawing from diverse urban policy contexts with consideration of similarities to and differences in terms of local conditions, opportunities for green growth in cities, and enabling strategies for implementing urban green growth.

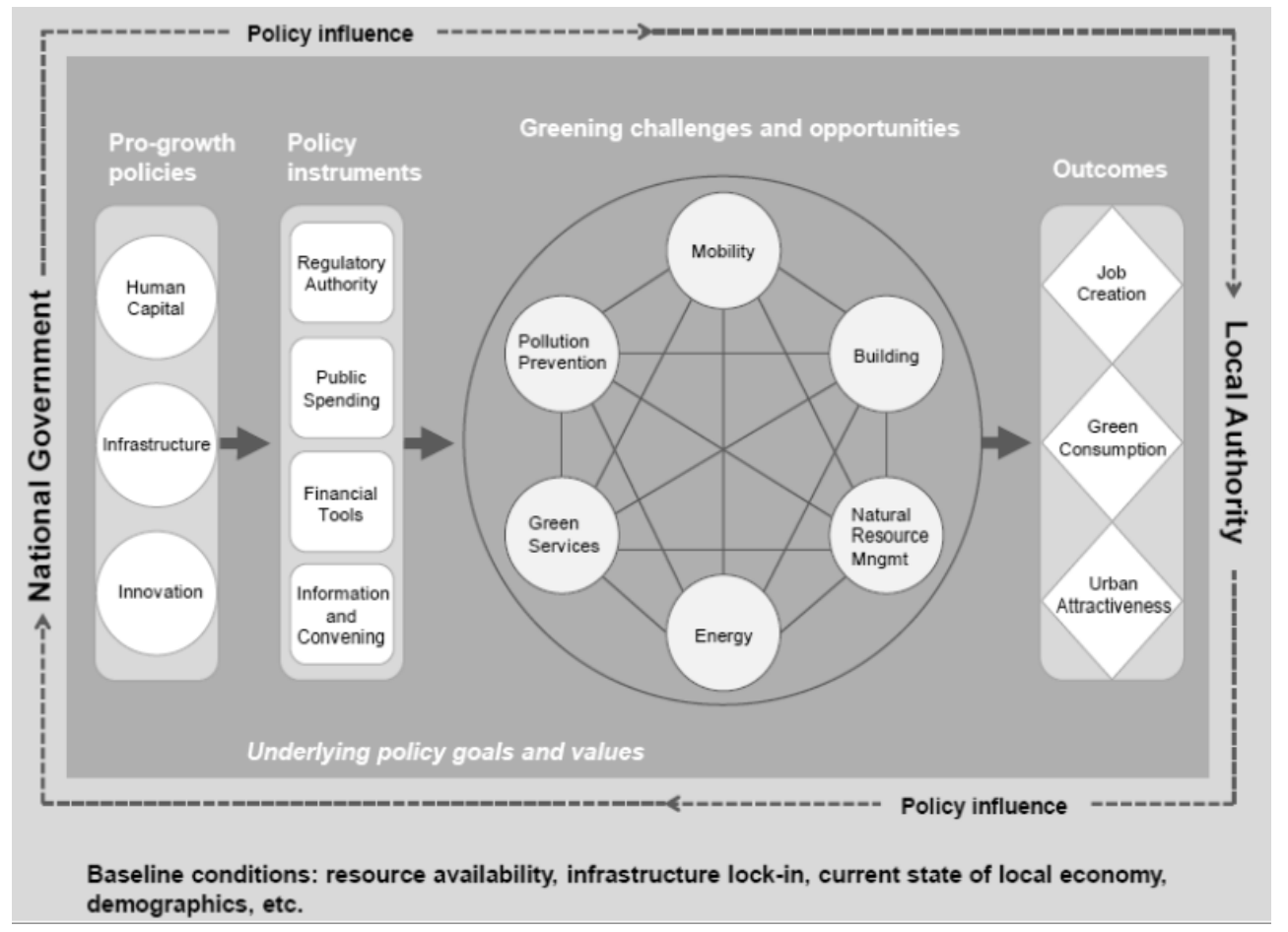

Figure 2. Conceptual framework on urban green growth (after Hammer et al., 2011a) 


\section{Macrothink}

The framework can be applied in the context of Bamenda with respect to the opportunities for direct and indirect employment emanating from the green space project and its ability to support urban beautification in the city. Such an action requires the City Council and other urban development stakeholders to promote infrastructural development (beginning from slope stabilization) and to increase public spending to ensure urban green growth. Above all, a revisit of the urban development framework to capture or re-emphasize green growth policies and their enabling implementation strategies in this fast-growing city is unavoidable. The concept by Hammer et al. (2011) could be complemented by Zhou and Md. Masud (2012) who employed a systematic approach to develop a framework that quantifies social benefits of green space from provider and consumer perspectives. Providers in the context of this study include the City Council and government line ministries, while the consumers relate to the city dwellers of Bamenda including tourist and visitors into the town. Perhaps, a social valuation of urban green spaces from the perspective of providers and consumers could further generate information on the opportunities associated with the project.

\section{Study Area and Research Methods}

Bamenda is the capital of the North West Region (Figure 3). As the primate city in the region, it is by its population the third city in Cameroon after Douala and Yaoundé (BUCREP, 2005). Bamenda lies between latitude $5^{\circ} 94^{\prime} \mathrm{N}$ and $5^{\circ} 98^{\prime} \mathrm{N}$ and longitudes $10^{\circ} 15^{\prime} \mathrm{E}$ and $10^{\circ} 18^{\prime} \mathrm{E}$. It sits along the Cameroon Volcanic Line with two distinct relief features: a High Lava Plateau of about $1,400 \mathrm{~m}$, and the Lower Plateau, with an average altitude of 1,100 $\mathrm{m}$ above sea level both separated by a vast escarpment.

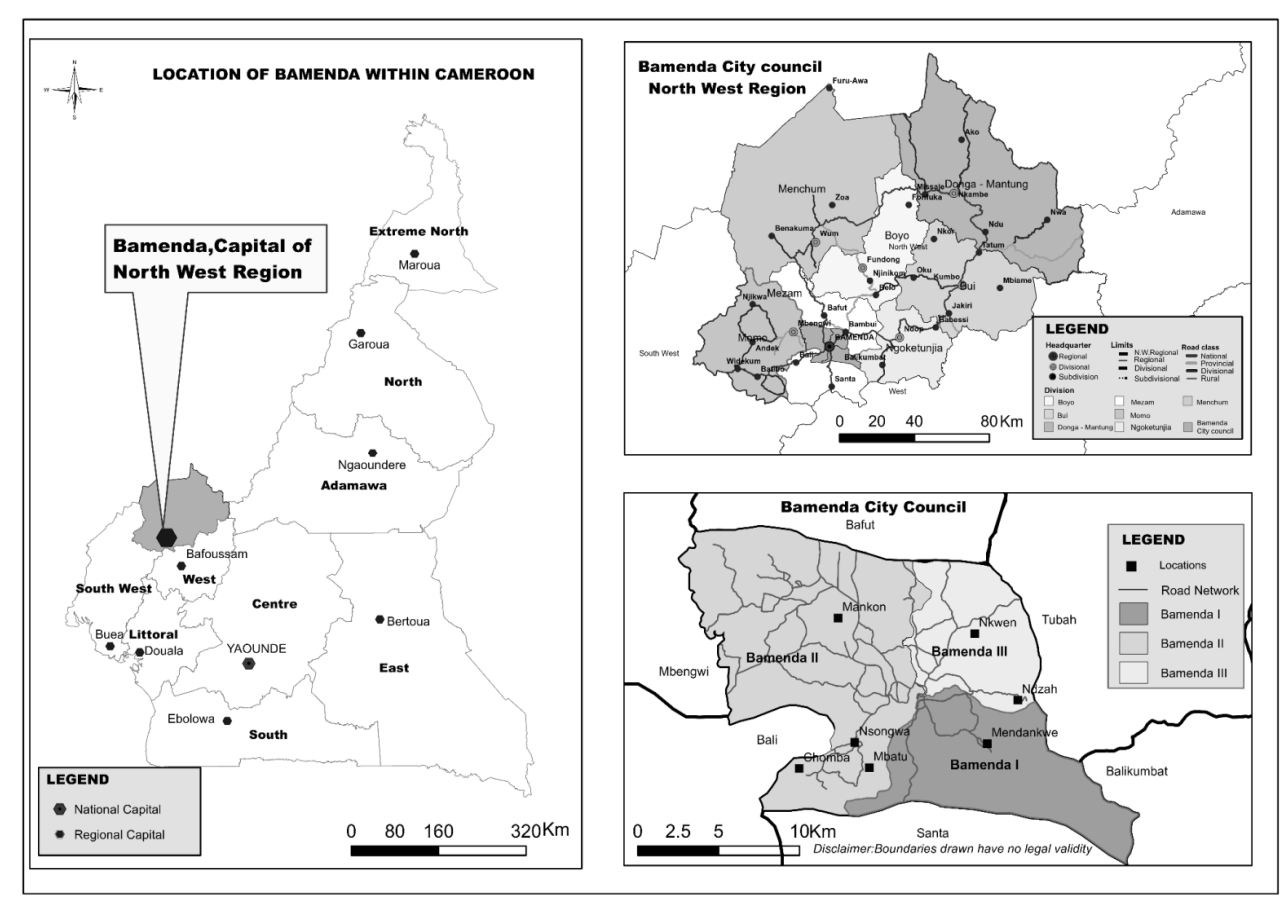

Figure 3. Map of Bamenda Urban Area in North West Cameroon

(Source: BCC, 2016)

The surface area of Bamenda is estimated at $30 \mathrm{~km}^{2}$ and the town hosts over 269530 
inhabitants (BUCREP, 2005). Bamenda has a tropical climate with two seasons - a long rainy season of eight months (March to October) and a short dry season of four months. Temperature varies between $15-31^{\circ} \mathrm{C}$. The 5 hectare parcel of land is found within the Bamenda I municipality on the Bamendankwe Escarpment commonly called the Station Hill (Figure 4).

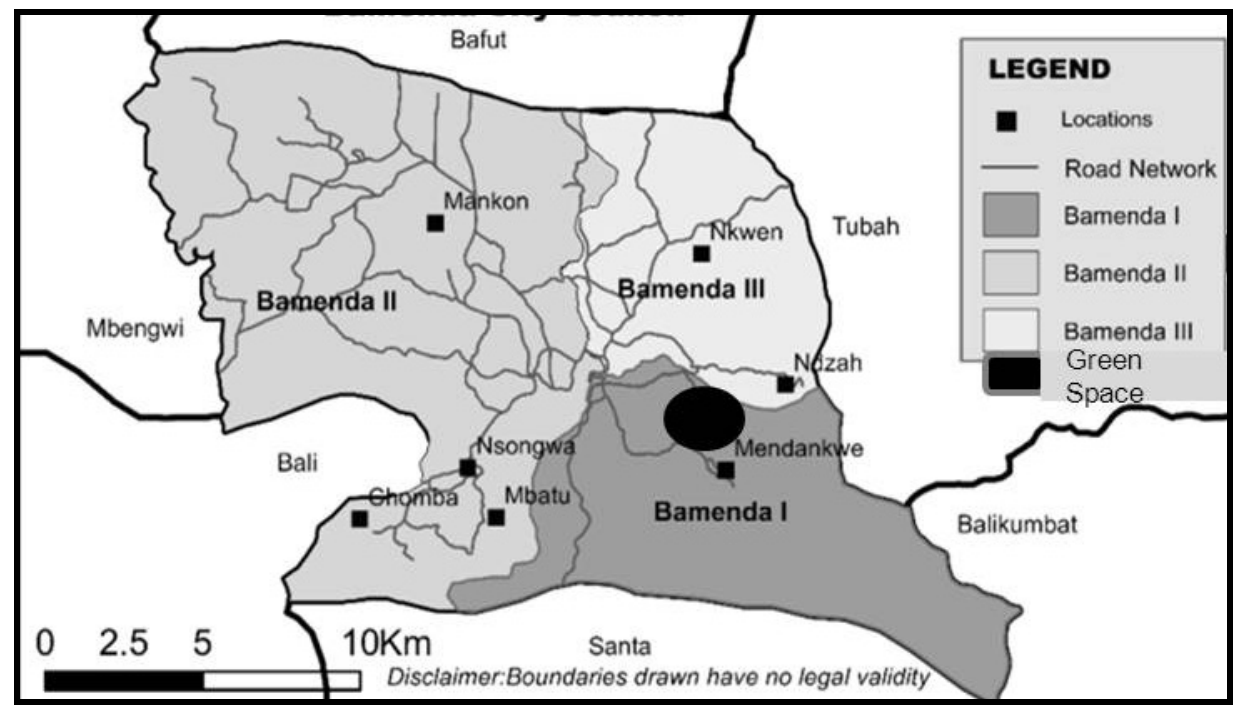

Figure 4. Map of the Bamenda City showing the Urban Green Space site

A combination of primary and secondary data were used in this study. Primary data were gotten from interviews of 50 inhabitants around the escarpment. This involved farmers, traders and other service providers. A purposive sampling was employed in which 50 inhabitants who lived at an estimated radius of $4 \mathrm{~km}$ around the target site were sampled. This was complemented by secondary data and interviews of council authorities. Field observations were conducted at the project site to appreciate signatures of slope failure and other human threats to the preservation of the park space. Based on background experiences and knowledge on the nature of the study area, focus group discussions were conducted with the municipal authorities and other community members to obtain a proper orientation on possible challenges to the success of the project with a view to identifying pathways to overcome them. The participants selected were between the ages of 30-50 years and they involved those who had lived in the vicinity for at least 5 years. Interviews and questionnaires were administered in Pidgin English in some cases to ease comprehension. Care was however taken not to distort the sense or content of the question. The exercise was participatory as much as possible to give room for participants to fully express their views on the issues. Information regarding associated employment (direct and indirect) was captured in the questionnaire. In this case, respondents were provided with some possible employment opportunities (hotel and catering, retail services, transport and green space maintenance operators among others) and they indicated their opinion on the possible employment opportunities. Secondary data (maps and project documents) were obtained from the Bamenda City Council in complementarity with that from the Training Seminar organized by the City Council and UN-Habitat from the 16 to 19 August 2016. The training served as a 
start-up process for data collection on open public space and city parks in Bamenda in the face of population increase. It was meant to train stakeholders on the use of modern urban public space data collection tools (Mind craft and KOBO Tool Box) to map out green and open spaces in Bamenda. This was followed by the application of the data collection tools (Mind craft and KOBO Tool Box) by participant with the use of smartphones to identify public spaces.

Based on the interactions through interviews, complemented by secondary sources and ideas from the training workshop, the study used the content analysis technique to examine the urban development opportunities and challenges of the urban greening project. This saw the transcription and examination of participant's diverse opinions. One key challenge observed in this method is that it does not express the opinion in quantitative terms and no simulation model was developed to project future developmental scenarios of the urban green space. The study however preferred the use of content analysis technique to carry on the analysis without eliminating or suppressing the views expressed through interviews and focus groups discussions. Descriptive analysis was equally employed to include the use of pie charts to present the opinion of respondents with respect to the opportunities and challenges of urban greening. The digital elevation range of the Bamenda escarpment was developed by CAMGIS using GIS and Remote Sensing softwares.

\section{Results and Discussion}

\subsection{The Bamenda Urban Greening Project}

Considering the current and projected demographic pressure in Bamenda, the Bamenda city council sought to partner with national and international stakeholders to support the coordination of her development, with a view to greening its brown development. In line with efforts geared towards the attainment of Sustainable Development Goal 11- "Make cities and human settlements inclusive, safe, resilient and sustainable", the Bamenda City council and the Dordrecht/Gorinchem City Councils of the Netherlands entered into partnership with the United Nations Human Settlement programme (UN-Habitat) in August 2016. This partnership was established in a bid to seek ways of coordinating the use and development of urban space and to ensure urban greening. Prior to this collaboration, urban space, especially potential greening sites were subjected to constant encroachment by agriculture and other land uses. These activities exposed the slopes to vegetal clearing and exposure, bushfires and a series of mass wasting episodes especially landslides. In this regard, the Bamenda City Council (BCC) in 2011 identified the slopes of the Bamenda escarpment for protection (Fig. 5). This permitted the creation of the Green City Initiative. The opportunities and challenges require scientific assessment in the face of rapid population growth. 


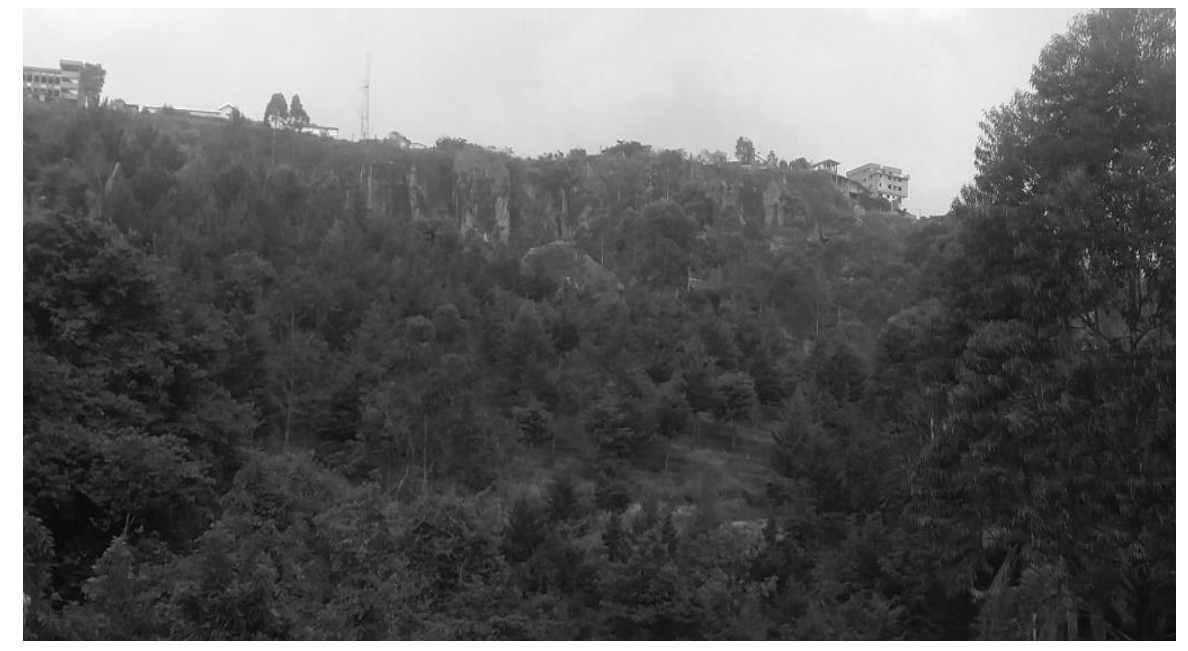

Figure 5. Partial View of the Urban Greening Project site

(Fieldwork, April 2017)

\subsection{Urban Greening Opportunities and Challenges}

Based on the respondent's viewpoint, the Bamenda urban greening project presents socio-economic opportunities to include among others, the provision of employment $(28 \%)$ especially for marginalized segments of the population, revenue generation for the city council $(22 \%)$ and the promotion of urban beauty $(18 \%)$ among others. Respondents indicated a number of employment opportunities to include hotel and catering, retail services, transport and green space maintenance operation, among others. The project will equally be beneficial through its control on urban sprawl and slope stabilization (Figure 6).

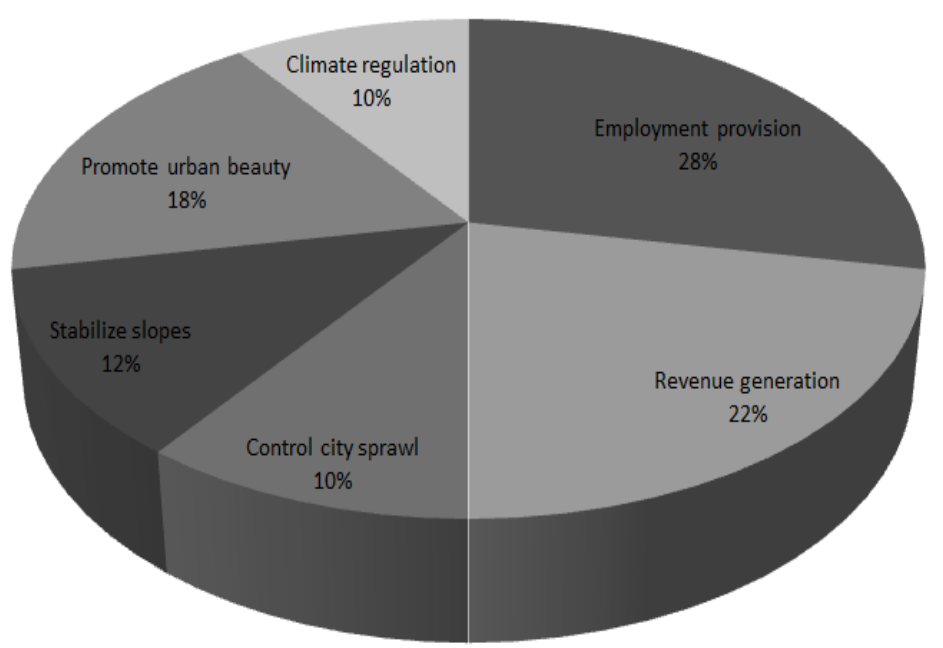

Figure 6. Respondents opinion on the envisaged benefits of the project

Despite the envisaged opportunities, a number of challenges (Figure 7) are envisaged which can hinder green development in Bamenda. These challenges include the unstable nature of the foothill slopes (30\%), land use competition as a result of demographic pressures $(24 \%)$, the 


\section{Macrothink}

International Journal of Global Sustainability

ISSN 1937-7924

2017, Vol. 1, No. 1

mismanagement of urban space by dwellers $(20 \%)$ and relocation costs for already occupies land $(14 \%)$.
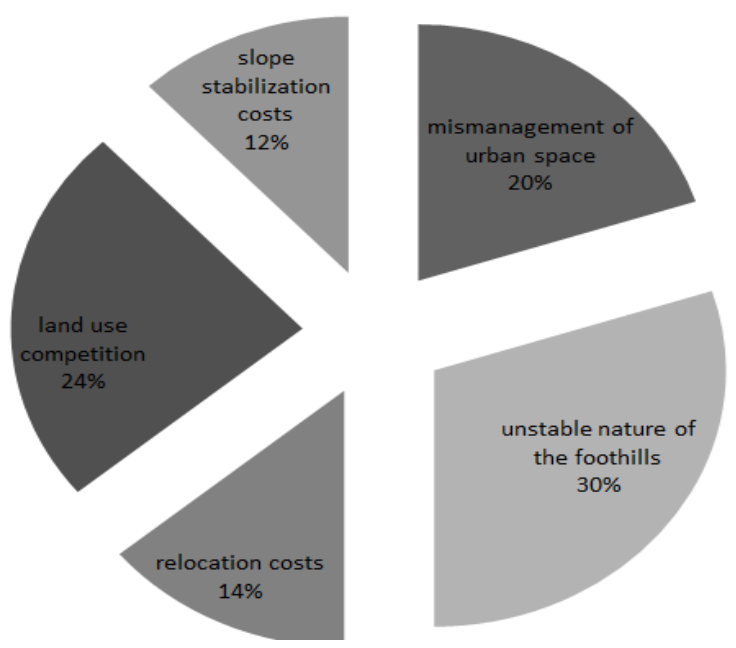

Figure 7. Respondents opinion on the challenges of the urban green project

The foothill slopes of the Bamenda escarpment are a major geomorphological and dynamic amphitheatre terrain where landslides and other forms of slope failure are equal to no other part of the North West Region. This high elevation area (Fig. 8) is a volcanic terrain with rock characteristics of a geo-hydromorphic sponge. This makes the area best fit for landslides and other mass wasting phenomena. Its instability which is accounted for by its hydrogeomorphology has been accentuated by vegetal clearing for agriculture and other land uses.

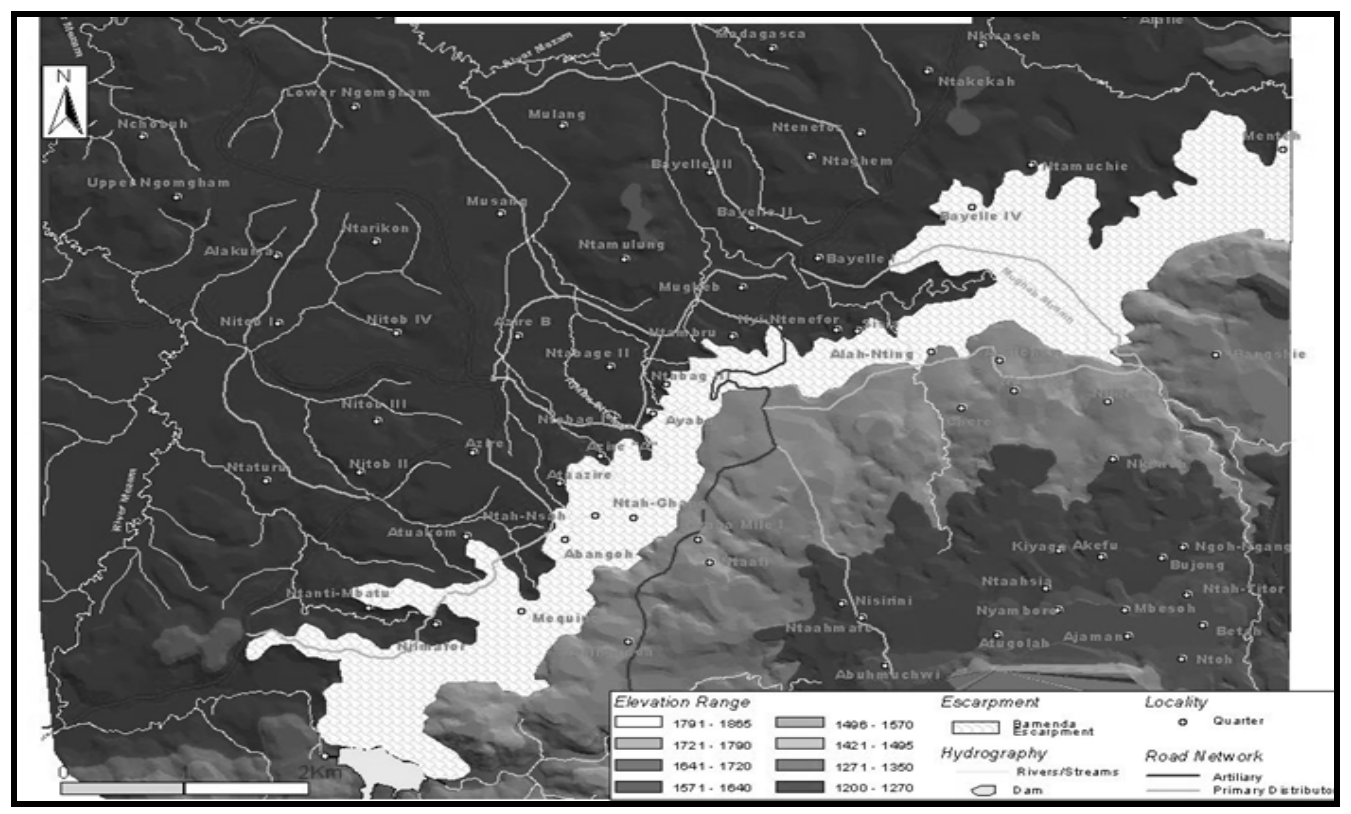

Figure 8. The digital elevation range of Bamenda including the Bamenda escarpment (Source: Adapted from CAMGIS). 
Equally, urban green projects face competition from other land users. Cognisant that this initiative is new in the environment, trading initial activities (agriculture and settlement) in favour of the urban greening project represents an important challenge to be overcome. This could further be compounded by poverty and cultural preferences. The limited usage of green environments in cities has been attributed to socio-cultural (poverty, cultural preferences) and socio-spatial determinants (travel distance, park features). One of the reasons could be that the park space may be perceived as unsafe or "belonging" to another group in the community (Brownlow, 2006; Stodolska et al., 2011). This view is further shared by Byrne (2012) who, working with low-income Latinos in Los Angeles illustrates how ethno-racial formations, histories of segregated park systems, and land-use regulation can circumscribe park access and use (Wolcha et al., 2014). The growing population could introduce issues of land use competition as urban dwellers encroach into the area in search for livelihoods with activities such as farming with the use of the slash-and-burn method, water exploitation, the search for fuel wood, and the establishment of informal settlements. Pressure from urbanization is considered as a unique driving force for degrading urban green space. Fernan et al. (2011) observed that high rates of urban expansion and the growth of informal settlements have compromised green space within and at the periphery of Abuja. This saw the size of urban green space reducing from $21 \%$ to $12.9 \%$ (Fenan et al., 2011). Such a situation is observed for other cities in Sub Saharan Africa. For instance, Dubbale et al. (2010) reported a massive destruction of green spaces in Addis Ababa, Klopp (2012) indicated that the Karuna Forest in Nairobi was encroached upon by over 3000 ha. In a related dimension, Salama (2012) reported a loss of many urban green spaces in Cairo and other urban centres in Egypt (Salama, 2012). To solve this, a clear demarcation of the area followed by an enforcement of laws against encroachment of these competing activities is a logical step towards reversing the negative trend of events in the park space.

The issue of mismanagement of urban space is mirrored in the poor enforcement of development controls and the lack of political will. This is a recurrent urban planning defect in most developing world cities. In Cameroon, the few urban green space initiatives in the major cities of Yaounde and Douala face a series of challenges. Some of these challenges include bureaucratic bottlenecks that characterize planning authorities with respect to issuing development permits. This long and frustrating process force developers and other individuals in urban areas to evade the required planning procedures, and to embark on land projects which are unauthorised. The resultant effect is the massive encroachment into green space environments by commercial and residential activities. In a related dimension, bureaucratic bottlenecks have encouraged bribery and corruption practices by planning authorities (Awuah et al., 2010; Mensah, 2014). Furthermore, the poor involvement of urban residents coupled with limited sensitization and awareness on the benefits of green initiatives has been identified as another challenge within the Cameroonian urban landscape. This has caused city residents to consider urban green space protection as the sole responsibility of planning authorities. The resultant effect has been the significant destruction of green spaces by the local people and their conversion into dump sites (Djibril et al., 2010; Muhumuza \& Balkwill, 2013; Mensah, 2014). This could be further aggravated by poor operation and maintenance of the urban green space. In Kumba for instance, no sooner had the Amusement Park began its operation than it had 
witnessed a decline which could be largely attributed to poor management. Mpofu (2013) reported cases where beautification projects were halted in Addis Ababa largely due to mismanagement. Poor maintenance of urban parks and other green spaces which represent institutional inefficiencies were observed for Kumasi in Ghana, Abidjan in Cote d'lvoire and Harare in Zimbabwe (Mensah, 2014; Djibril et al., 2012).

\section{Conclusion and Recommendations}

This paper provides some reflections on the urban development planning opportunities and challenges of the Bamenda urban greening project with a view to identifying what should be done to successfully green a brown development in Bamenda. The issue of urban greening is topical given the current rate of urban development which mounts pressure on the environment. In concrete terms, it is estimated that by 2050, 6.3 billion people will populate cities. This indicates a logical increase in the demand for urban green space to accommodate physical activity. Such space is likely to include a mixture of green streets, pocket parks, larger parks, and other areas. Common standards would be helpful in defining appropriate thresholds around with regards to the provision, quality and accessibility, among others of green space. The WHO for instance considers access to parks within a 300metres range (Shepley et al., 2014). The Bamenda Urban greening initiative presents a series of envisaged socio-economic and environmental benefits. However, this is against the backdrop of a number of environmental and largely institutional challenges such as the unstable nature of the foothill slopes, competing land uses as a result of demographic pressures, and the mismanagement of urban space by city dwellers. Emphasis should be directed towards effective sensitization and integration of local stakeholders who should be schooled to understand the value chain of the green space. These stakeholders should understand their roles and responsibilities in the project and their benefits at each stage of the chain. In this regard, the following recommendations are proposed:

1) Mindful that the adjacent populations are predominantly agrarian in nature, urban stakeholders ought to guard against the encroachment of bush fires which are common during the planting seasons. This could have a destabilizing effect on the green space ecosystem. Fire tracing would be effective and the communities around should serve as monitoring agents. Initial efforts to protect the site which began in 2011 should be intensified.

2) City authorities should be engaged to conduct a permanent surveillance against the encroachment of competing land uses in this area, especially agriculture and settlement. There should equally be the introduction of a relocation programme for initial settlers to ensure their re-establishment away from the urban green space.

3) Although some initial sensitization has been carried out by the council to school farmers to protect the trees planted and to continually adjust their activities with time as the tree covers gets dense in the project site, it is necessary to reinforce such an understanding to ensure effectiveness in the activities. For this to be sustainable, an integrated approach involving planning, monitoring, designing and maintaining of urban green spaces is required for improving the sustainability of such an environmental initiative within the Bamenda City.

\section{References}

Abercrombie, L. C., Sallis, J., Conway, T., Frank, L. D., Saelens, B. E., \& Chapman, J. E. 
(2008). Income and racial disparities in access to public parks and private recreation facilities. American Journal of Preventative Medicine, 34(1), 9-15. https://doi.org/10.1016/j.amepre.2007.09.030

Asian Development Bank. (2015). Green City Development Toolkit. Asian Development Bank, 2015, Phillipines.

Atiqul Haq, S. Md. (2011). Urban Green Spaces and an Integrative Approach to Sustainable Environment. Journal of Environmental Protection, 2, 601-608. https://doi.org/10.4236/jep.2011.25069

Awuah, K. G. B., Hammond, F. N., Block, R., Proverbs, D., Booth, C. et al. (2010). SubSaharan Africa urban land use planning systems: The need for an economic appraisal. A paper presented at the Construction, Building and Real Estate Research Conference of the Royal Institution of Chartered Surveyors. Paris, September 2-3.

Balgah, S. N., \& Kimengsi, J. N. (2016). Land Use Dynamics and Wetland Management in Bamenda: Urban Development Policy Implications. Journal of Sustainable Development, 9(5), $1-11$.

Balram, S., \& Dragićević, S. (2005). Attitudes Toward Urban Green Spaces: Integrating Questionnaire Survey and Collaborative GIS Techniques to Improve Attitude Measurements. Landscape and Urban Planning, 71(2), 147-162. https://doi.org/10.4236/jep.2011.25069

Bender, D. J., Contreras, T. A., \& Fahrig, L. (1998). Habitat loss and population decline: A meta analysis of the patch size effect, Ecology, 79, 517-533. https://doi.org/10.1890/0012-9658(1998)079[0517:HLAPDA]2.0.CO;2

Benninger, C. (2001). Principles of intelligent urbanism. Ekistics, 69(412), 39-65.

Blanco, H., Alberti, M., Forsyth, A., Krizek, K. J., Rodriguez, D. A., \& Talen, E. (2009). Hot, congested, crowded and diverse: Emerging research agendas in planning. Progress in Planning, 71(4), 153-205. https://doi.org/10.1016/j.progress.2009.03.001

Brownlow, A. (2006). An archaeology of fear and environmental change in Philadelphia. Geoforum, 37, 227-245. https://doi.org/10.1016/j.geoforum.2005.02.009

Byrne, J. (2012). When green is White: The cultural politics of race, nature and social exclusion in a Los Angeles urban national park. Geoforum, 43(3), 595-611. https://doi.org/10.1016/j.geoforum.2011.10.002

Cameroon Vision 2035 Working Paper, February 2009. General Secretariat of Forecast and Strategic Planning Division of the Ministry of the Economy, Planning and Regional Development.

Ch'ng, E. (2011). Digital Heritage Tourism: Reconfiguring the Visitor Experience in Heritage Sites, Museums and Architecture in the Era of Pervasive Computing, Percor si creative di turismo urbano (Creative Paths of Urban Tourism) Conference, Catania, 22-24 September 2011. Pàtron, Bologna.

Cilliers, E. J., Timmermans, W., Van Den Goorbergh, F., \& Slijkhuis, J. S. A. (2015a). Green Place-making in Practice: From Temporary Spaces to Permanent Places. Journal of Urban Design, 20(3), 349-366. https://doi.org/10.1080/13574809.2015.1031213

Cilliers, J., \& Cilliers S. (2016). Planning for Green Infrastructure: Options for South African 
cities. Unit for Environmental Sciences and Management North-West University, Potchefstroom.

Cilliers, E. J., \& Goosen, Z. (2016). The Planning and Development of Green Public Places in Urban South Africa: A Child-Friendly Approach. International Journal of Civil, Environmental, Structural, Construction and Architectural Engineering, 10(7).

Dahmann, N., Wolch, J., Joassart-Marcelli, P., Reynolds, K., \& Jerrett, M. (2010). The active city? Disparities in provision of urban public recreation resources. Health and Place, 16(3), 431-445. https://doi.org/10.1016/j.healthplace.2009.11.005

Djibril, C., Coulibaly, A., Wang, X., \& Ousmane, D. (2012). Evaluating green space use and management in Abidjan City, Cote D'lvoire. International Journal of Economics and Management Engineering, 2(3), 108-116.

Fogwe, Z. N., Orock F. T., \& Samgwa, I. (2016). Developing urban Water resources and contamination risks on the population of Cameroon: a Bamenda example, Journal of Global Ecology and Environment, 4(2), 102-110.

Fogwe, Z. N. (2016). An Assessment of an Urban Development-Flood-Impact Relationship in a Near Millionaire City of Cameroon (Bamenda). Journal of Geoscience and Environment Protection, 4, 136-146. https://doi.org/10.4236/gep.2016.44017

Forman, R. T. T. (1996). Land Mosaics: The Ecology of Landscapes and Regions. Cambridge: Cambridge University Press.

Fuller, R. A., \& Gaston, K. J. (2009). The scaling of green space coverage in European cities. Biology Letters, 5(3), 352-355. https://doi.org/10.1098/rsbl.2009.0010

Galvin, M., \& Payne, S. E. (2010). Bulwer Park Revitalization Strategy. http://bit.ly/1tbJUWK. Date of access: 29 Mar. 2016.

Gairola, S., \& Noresah, M. S. (2010). Emerging trend of urban green space research and the implications for safeguarding biodiversity: a viewpoint. Nature and Science, 8(7), 43-49.

Girling, C., \& Kellet, R. (2005). Skinny Streets and Green Neighborhoods: Design for Environment and Community. Washington, Island Press.

Grahn, P., \& Stigsdotter, U. A. (2003). Landscape Planning and Stress. Urban Forestry \& Urban Greening, 2(1), 1-18. https://doi.org/10.1078/1618-8667-00019

Greater London Assembly. (2011). The London Plan: Spatial development strategy for greater London, London: GLA.

Hague, M., \& Siegel, N. (2002). Municipal parks in New York City: Olmsted, Riis, and the transformation of the urban landscape, 1858-1897. In Backhaus G, Murungi J, (Eds.) Transformations of Urban and Suburban Landscapes: Perspectives from Philosophy, Geography, and Architecture. Lexington Books, Lanham, MD. 2002; 153-191.

Hammer, S., Kamal-Chaoui, L., Robert, A., \& Plouin, M. (2011a). Cities and Green Growth: A Conceptual Framework, OECD Regional Development Working Papers, OECD Publishing, Paris.

Hodson, M., \& Marvin, S (2009). Urban Ecological Security: A New Urban Paradigm? International Journal of Urban and Regional Research, 33, 1193-215. https://doi.org/10.1111/j.1468-2427.2009.00832.x 
Jabareen, Y. R. (2006). Sustainable Urban Forms: Their Typologies, Models and Concepts. Journal of Planning Education and Research, 26, 38-52. https://doi.org/10.1177/0739456X05285119

Jennings, V., Johnson-Gaither, C., \& Gragg, R. S. (2012). Promoting environmental justice through urban green space access: A synopsis. Environmental Justice, 5(1), 1-7. https://doi.org/10.1089/env.2011.0007

Kometa, S. S., \& Ndi, R. A. (2012). The Hydro-Geomorphological Implications of Urbanization in Bamenda Cameroon; Journal of Sustainable Development, 5(6). https://doi.org/10.5539/jsd.v5n6p64

Lee, K. J., Han, B. H., \& Choi, J. W. (2005). A study on the characteristics of urban ecosystems and plans for the environment and ecosystem in Gangnam-gu, Seoul, Korea, Landscape and Ecological Engineering, 1, 207-219. https://doi.org/10.1007/s11355-005-0025-x

Mckinney, M. L. (2005). Urbanization, biodiversity, and conservation. BioScience, 52, 883-890. https://doi.org/10.1641/0006-3568(2002)052[0883:UBAC]2.0.CO;2

Mensah, C. A. (2014). Urban Green Spaces in Africa: Nature and Challenges. International Journal of Ecosystem, 4(1), 1-11.

Milton, K. (2002). Loving Nature: Towards an Ecology of Emotion. Routledge, New York. https://doi.org/10.4324/9780203421413

Muhumuza, M., \& Balkwill, K. (2013). Factors affecting the success of conserving biodiversity in national parks: A review of case studies from Africa. International Journal of Biodiversity. https://doi.org/10.1155/2013/798101

Peschardt, K. K., Schipperijn, J., \& Stigsdotter, U. K. (2012). Use of Small Public Urban Green Spaces (SPUGS). Urban forestry \& Urban Greening, 11(3), 235-244. https://doi.org/10.1016/j.ufug.2012.04.002

Sachikonye, M. T. B., Dalu, T., \& Gunter, A. (2016). Sustainable livelihood principles and urban greening in informal settlements in practice: A case of Zandspruit informal settlement, South Africa. Development Southern Africa, 33, 518-531. https://doi.org/10.1080/0376835X.2016.1179101

Sandstrom, U. G., Angelstam, P., \& Khakee, A. (2006). Urban comprehensive planning: identifying barriers for the maintenance of functional habitat networks. Landscape and Urban Planning, 75, 43-57. https://doi.org/10.1016/j.landurbplan.2004.11.016

Shackleton, C. M., \& Blair, A. (2013). Perceptions and use of public green space is influenced by its relative abundance in two small towns in South Africa. Landscape and urban Planning, 113, 104-112. https://doi.org/10.1016/j.landurbplan.2013.01.011

Shepley, O., Paskins, J., \& Chaytor, S. (2014). Valuing Urban Green Space: Challenges and Opportunities, UCL Policy Briefing-October 2014

Stodolska, M., Shinew, K. J., Acevedo, J. C., \& Izenstark, D. (2011): Perceptions of urban parks as havens and contested terrains by Mexican-Americans in Chicago neighborhoods. Leisure Sciences, 33(2), 103-126. https://doi.org/10.1080/01490400.2011.550220

Sutton, C. M. (2006). On urban open space: a case study of Msunduzi Municipality, South Africa. Canada: Queens University. (Thesis - BSc). School of Environmental Studies. 


\section{Macrothink}

Tuzin, B., Leeuwen, E., Rodenburg C., \& Peter, N. (2002). Paper presented at the 38th International Planning Congress on "The Pulsar Effect" Planning with Peaks, Glifada, Athens, 21-26 September 2002.

United Nations Economic Commission for Africa (UNECA, 2016). Greening Africa's Industrialization. Economic Report on Africa by the Economic Commission for Africa.

UN-Habitat (2009). Harmonious Cities: State of the World's Cities 2008/2009, London. www.clc.org.sg/pdf/UN- habitat20 Report\%20Overview.pdf Accessed on 30/09/2009.

Walmsley, A. (2006). Greenways: multiplying and diversifying in the $21^{\text {st }}$ Century. Landscape and Urban Planning, 76, 252-290. https://doi.org/10.1016/j.landurbplan.2004.09.036

Williams, T. (2003). Smart advice for urban growth. Regeneration \& Renewal, 6 June.

Wolcha, J. R., Byrne, J., \& Newell, J. P. (2014). Urban green space, public health, and environmental justice: The challenge of making cities just green enough. Landscape and Urban Planning, 125, 234-244. https://doi.org/10.1016/j.landurbplan.2014.01.017

Yli-Pelkonen, V., \& Niemela, J. (2005). Linking ecological and social systems in cities: urban planning in Finland as a case. Biodiversity and Conservation, 14, 1947-1967. https://doi.org/10.1007/s10531-004-2124-7

Zhou, X., \& Md. Masud, P. R. (2012). Social benefits of urban green space: A conceptual framework of valuation and accessibility measurements. Management of Environmental Quality: An International Journal, 23(2), 173-189. https://doi.org/10.1108/14777831211204921

\section{Copyright Disclaimer}

Copyright for this article is retained by the author(s), with first publication rights granted to the journal.

This is an open-access article distributed under the terms and conditions of the Creative Commons Attribution license (http://creativecommons.org/licenses/by/3.0/). 